\title{
Chemical composition, antibacterial and antifungal activities of essential oil from Cordia verbenacea DC leaves
}

\author{
Fabiola F. G. Rodrigues, Liana G. S. Oliveira, Fábio F. G. Rodrigues, Manuele E. Saraiva, \\ Sheyla C. X. Almeida, Mario E. S. Cabral, Adriana R. Campos ${ }^{1}$, Jose Galberto M. Costa \\ Department of Biological Chemistry, Molecular Bioprospection Post-graduation Program, Laboratory of Natural Products Research, Regional \\ University of Cariri, Crato, CE, Brazil, ${ }^{1}$ Vice-Rectory of Research and Post-Graduation, University of Fortaleza, Fortaleza, CE, Brazil \\ Submitted: 18-09-2011 \\ Revised: 03-12-2011 \\ Published: 27-07-2012
}

A B S T R A C T

Background: Cordia verbenacea is a Brazilian coastal shrub popularly known as "erva baleeira". The essential oil from fresh leaves was obtained by hydrodistillation and analyzed by CG/MS. The main components were identified as $\beta$-caryophyllene $(25.4 \%)$, bicyclogermacrene $(11.3 \%)$, $\delta$-cadinene $(9 . \%)$ and $\alpha$-pinene $(9.5 \%)$. In this study, the antimicrobial activity of Cordia verbenacea was evaluated. Materials and Methods: The minimal inhibitory concentration (MIC) of the essential oil was obtained using the broth microdilution assay (from 512 to $8 \mu \mathrm{g} / \mathrm{ml}$ ). Results: The results showed that the essential oil presented fungistatic activity against Candida albicans and Candida krusei and antibacterial activity against Gram-positive strains (Staphylococcus aureus and Bacillus cereus) and against multiresistant Gram-negative (Escherichia coli 27), in all tests the MIC was $64 \mu \mathrm{g} / \mathrm{ml}$. When the essential oil was associated to aminoglycosides (subinhibitory concentrations, $\mathrm{MIC} / 8)$, a synergic and antagonic activity was verified. The synergic effect was observed to the amikacin association (MIC reduction from $256 \mathrm{mlto} 64 \mu \mathrm{g} / \mathrm{ml}$ ) in all strains tested. Conclusion: The essential oil of Cordia verbenacea influences the activity of antibiotics and may be used as an adjuvant in antibiotic therapy against respiratory tract bacterial pathogens.

Key words: Aminoglycosides, antimicrobial activity, Cordia verbenacea, essential oil

\section{INTRODUCTION}

Many species of plants distributed throughout Brazilian territory are used in popular medicine and pharmacology..$^{[1]}$ The interest in studying these plants is regarding their biological activities that are related to the secondary metabolites. These secondary metabolites are used as active principles in drugs or as chemical models for synthesis and semi-synthesis of drugs. ${ }^{[2]}$ The volatile substances are extracted from essential oils and they are important sources used in pharmaceutical, cosmetic and food industries. The majority of these essential oils present confirmed therapeutic properties, including the antimicrobial activity against a great number of bacteria and fungi, besides the resistant strains. Researches prove that $60 \%$ of the essential oils are antifungal and that $35 \%$ are

\section{Address for correspondence:}

Dr. José Galberto M. Costa, Department of Biological Chemistry,

Regional University of Cariri, Rua Cel. Antônio Luiz 1161,

Pimenta - 63105-000, Crato-CE, Brasil.

E-mail: galberto.martins@gmail.com antibacterial. ${ }^{[3,4]}$ There is an alarming increase of antibiotic resistance of several pathogens and this is driving the need for new agents to combat the infections. ${ }^{[5]}$

The Boraginaceae family comprises about 100 genera and 2.000 species, distributed throughout the tropical, subtropical, and temperate regions of the world. Cordia is the best represented genus of this family in Brazil. ${ }^{[6]}$ The genus Cordia contains approximately 250 species that are known to produce substances used as medicines and many species present medicinal use. ${ }^{[7]}$

Cordia verbenacea DC, known as "erva baleeira", is a shrubby species native to sandbank environments along the Brazilian coast. Its aromatic leaves are used in folk medicine as antiinflammatory, analgesic, anti-ulcerogenic and healing agent, in the form of teas or infusions for internal or topical use. $^{[8,9]}$ Phytochemical studies of $C$. verbenacea aerial parts identified the presence of monoterpenes, sesquiterpenes ${ }^{[10]}$ and triterpenos. ${ }^{[1]}$

The search of new antibiotic classes with action against 
diverse bacteria strains has improved the studies with natural products adding to the fact that there was an increase in the studies of substances which could be associated to conventional antibiotics, and to enhance their action against the microorganisms.

\section{MATERIALS AND METHODS}

\section{Plant material}

Plant material of Cordia verbenacea DC. was collected from Horto de Plantas Medicinais of Regional University of Cariri, Crato - CE. A voucher specimen was deposited at the Herbário Prisco Bezerra of the Federal University of Ceará, under number \# 44171.

\section{Essential oil obtention}

Samples of C. verbenacea fresh leaves (750g) were triturated and submitted to hydrodistillation process, in a clevengertype apparatus for $2 \mathrm{~h}$, resulting in essential oil yield of $1.12 \%$. The collected essential oil (EOCv) was subsequently dried by anhydrous sodium sulfate $\left(\mathrm{Na}_{2} \mathrm{SO}_{4}\right)$, and stored under refrigeration at $<4^{\circ} \mathrm{C}$ until analyzed and tested.

\section{Analysis of the essential oil}

Analysis by CG/MS of EOLm was carried out on a Hewlett-Packard Model 5971 GC/MS using a non-polar DB-1 fused silica capillary column $(30 \mathrm{~m} \times 0.25 \mathrm{~mm}$ i.d., $0.25 \mu \mathrm{m}$ film thickness); carrier gas helium, flow rate $0.8 \mathrm{ml} / \mathrm{min}$ and with split mode. The injector temperature and detector temperature were $250^{\circ} \mathrm{C}$ and $200^{\circ} \mathrm{C}$, respectively. The column temperature was programmed from $35^{\circ} \mathrm{C}$ to $180^{\circ} \mathrm{C}$ at $4^{\circ} \mathrm{C} / \mathrm{min}$ and then $180 \mathrm{C}$ to $250^{\circ} \mathrm{C}$ at $10^{\circ} \mathrm{C} / \mathrm{min}$. Mass spectra were recorded from $30-450$ $\mathrm{m} / \mathrm{z}$. Individual components were identified by matching their $70 \mathrm{eV}$ mass spectra with those of the spectrometer data base using the Wiley L-built library and two other computer libraries MS searches using retention indices as a pre-selection routine, as well as by visual comparison of the fragmentation pattern with those reported in the literature. ${ }^{[12]}$

\section{Antibacterial activity and minimal inhibitory} concentration (IMIC)

The antibacterial activities of the essential oils were investigated by employing a microdilution method, recommended by M7-A6 (NCCLS, 2003). ${ }^{[13,14]}$ The assay was carried out with four bacterial species obtained from Fundação Oswaldo Cruz - FIOCRUZ: Staphylococcus aureus (ATCC 6538), Bacillus cereus ATCC 33018, Escherichia coli ATCC 25922 and Pseudomonas aeruginosa ATCC 15442 and two multiresistant strains obtained from clinical material: Escherichia coli (Ec 27) from sputum and Staphylococcus aureus (Sa 358) from surgical wound. Candida albicans ATCC 40006 and Candida krusei ATCC 6538 were used as fungi. Serial dilutions were performed by the addition of the BHI broth (bacteria) and Sabouraud Dextrose (yeast) to reach a final concentration in the range of $8-512 \mu \mathrm{g} / \mathrm{ml})$. The antimicrobial activity was indicated by resauzurin staining $(25 \mu \mathrm{L} ; 0.01 \%){ }^{[15]}$

Antibiotic modifying activity by direct contact In order to evaluate the EOCv as a modulator of antibiotic resistance, the MICs of aminoglycosides (neomycin, canamycin, amikacin and gentamicin) against the strains E. coli (Ec 27), S. aureus (Sa 358), P. vulgaris (ATCC 13315) and $S$. aureus (ATCC 12692) were determined in the presence or absence of EOCv using the microdutiltion test. Subinhibitory concentrations (MIC 1/8) in 10\% BHI were used.

The antibiotics solutions $(1.024 \mu \mathrm{g} / \mathrm{ml})$ were prepared in distillated water for use on the same day. $100 \mu \mathrm{L}$ of the antibiotic solution, using use serial dilutions (1:2) were added to the wells containing $10 \%$ BHI. Microplates were incubated for $24 \mathrm{~h}$ at room temperature and the antibacterial activity was determined as described before. ${ }^{[16]}$

\section{RESULTS AND DISCUSSION}

The GC/MS analysis of Cordia verbenacea essential oil permitted the identification and quantification of nineteen constituents $(93.5 \%)$, with predominance of sesquiterpenes $(83.66 \%)$, as $\beta$ - caryophyllene $(25.4 \%)$, bicyclogermacrene $(11.3 \%)$ and $\delta$-cadinene $(9.4 \%)$, besides the monoterpene a-pinene $(9.5 \%)$. The chemical composition is presented in Table 1 and the results found here are consistent with previous reports. ${ }^{[10]}$

Acheflan ${ }^{\circledR}$, an antiinflammatory recently launched in the market, is produced using the Cordia verbenaceae DC. extract. This extract contains $\alpha$-humulene and it is indicated as topical antiinflammatory to treat chronic tendinitis and myofascial pain. ${ }^{[17]}$ Besides the antiinflammatory activity, Cordia verbenaceae possess antimicrobial properties. This activity is probably related to the major component or the association of chemical compounds found in the essential oil. ${ }^{[18]}$

A study using the acetone extract from Cordia verbenaceae leaves identified the presence of triterpenes and flavonoids. ${ }^{[1]}$ An important antiinflammatory effect was attributed to artemetine, a flavone isolated from this specie. ${ }^{[1]}$

The essential from Cordia verbenacea showed antibacterial activity against the Gram-positive strains Staphylococcus aureus ATCC 12692 and Bacillus cereus and the multiresistant Gram-negative Escherichia coli 27 (MICs 64 gg/ml). Against Staphylococcus aureus 358 and Escherichia coli ATTC 25922, 
the essential oil presented a $512 \mu \mathrm{g} / \mathrm{ml}$ MIC. The results possess similarities with other studies, ${ }^{[10]}$ as the essential oil presented relevant antimicrobial activity against the most of Gram-positive strains [Table 2]. A study performed with the extract of $C$. verbenacea showed that this extract presents the same antimicrobial potential against Grampositive strains in comparison with the results obtained for Gram-negative strains. ${ }^{[19]}$

This diference between Gram-positive and Gram-negative sensibility can be related to chemical composition of the bacteria cell. Gram-negative cell walls contain a thin layer of peptidoglycan in comparison to Gram-positive bacteria. The lipidic content and chemical complexity of the cell wall of Gram-negative bacteria are considerably higher than Gram-positive. ${ }^{[0]}$

The difficulty in discovering new drugs using the traditional methods has been contributed to the problem of antibiotic

\begin{tabular}{lccc}
\multicolumn{4}{l}{$\begin{array}{l}\text { Table 1: Chemical components of the essential } \\
\text { oil from Cordia verbenaceae fresh leaves }\end{array}$} \\
\hline Components & $\mathbf{R T}^{\text {a }}$ (min) & $\mathbf{K I}^{\mathbf{b}}$ & $\mathbf{( \% )}$ \\
\hline$\alpha$-pinene & 5.2 & 933 & 9.5 \\
Sabinene & 6.2 & 972 & 0.9 \\
$\beta$-myrcene & 6.7 & 989 & 1.4 \\
$\beta$-phellandrene & 7.9 & 1027 & 0.4 \\
Linalool & 10.5 & 1099 & 0.5 \\
Camphor & 12.3 & 1141 & 0.5 \\
$\alpha$-terpineol & 13.7 & 1175 & 0.3 \\
$\alpha$-cubebene & 21.2 & 1348 & 0.6 \\
$\beta$-elemene & 23.7 & 1405 & 2.1 \\
$\beta$-caryophyllene & 24.3 & 1419 & 25.4 \\
$\alpha$-humulene & 25.6 & 1450 & 4.8 \\
$\beta$-farnesene & 25.8 & 1455 & 4.2 \\
germacrene D & 26.8 & 1478 & 4.5 \\
Bicyclogermacrene & 27.5 & 1495 & 11.3 \\
ß-bisabolene & 28.0 & 1508 & 3.2 \\
$\delta$-cadinene & 28.6 & 1522 & 9.4 \\
cadina-1,4-diene & 28.9 & 1532 & 5.9 \\
Spathulenol & 30.7 & 1575 & 5.7 \\
caryophyllene oxide & 30.9 & 1580 & 2.9 \\
Total & & & 93.5 \\
\hline
\end{tabular}

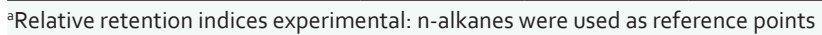
in the calculation of relative retention indices, ${ }^{b}$ Relative retention indices (literature values) resistance. These make the antibiotics more scarce and expensive. ${ }^{[21]}$ Therefore, it is important to highlight that the essential oil from C. verbenacea presented a considerable activity against Escherichia coli 27, a multiresistant bacteria which is an important public health problem. ${ }^{[22,23]}$

The evaluation of the antifungical activity was verified by the presence of colonies $\geq 100 \mathrm{CFU} / \mathrm{ml}$, because it is possible to affirm that the essential oil possess fungistatic activity against Candida albicans and Candida krusei (MIC $512 \mu \mathrm{g} / \mathrm{ml})$.

Human infections, particularly those involving the skin and mucosal surfaces, constitute a serious problem, especially in tropical and subtropical developing countries, dermatophytes and Candida sp. being the most frequent pathogens. ${ }^{[24]}$ However, the information available about medicinal plants active against this specie has not resulted yet in effective formulations to use in humans and animals. ${ }^{[25]}$

When the essential oil was associated to aminoglycosides (MIC 1/8), a synergistic effect was verified. The most expressive activity was the amikacin MIC reduction (256 to $64 \mu \mathrm{g} / \mathrm{ml}$ ), for all strains tested [Table 3]. The association between the amikacin, neomycin or gentamicin and the essential oil presented a synergic effect against the multiresistant E. coli 27.

Natural products from vegetable source (extracts and

\section{Table 2: Values of the minimal inhibitory concentration of the essential oil}

\begin{tabular}{lc}
\hline Strains & MIC $(\boldsymbol{\mu g} / \mathbf{m l})$ \\
\cline { 2 - 2 } & C. verbenacea \\
\hline E. coli ATCC 25922 & 512 \\
P. aeruginosa ATCC 15442 & $\leq 1024$ \\
B. cereus ATCC 33018 & 64 \\
S. aureus ATCC 12692 & 64 \\
E. coli 27 & 64 \\
S. aureus 358 & 512 \\
C. albicans ATCC 40006 & 512 \\
C. krusei ATCC 6538 & 512 \\
\hline
\end{tabular}

MIC: Minimal inhibitory concentration

Table 3: Minimal inhibitory concentration values of aminoglycosídes in the absence and presence of Cordia verbenaceae fresh leaves essential oil. The results are expressed as mean \pm DP $(n=3)$

\begin{tabular}{|c|c|c|c|c|c|c|}
\hline \multirow[t]{2}{*}{ Antibiotics } & \multicolumn{2}{|c|}{$\begin{array}{c}\text { S. aureus } \\
\text { ATCC } 12692\end{array}$} & \multicolumn{2}{|c|}{$\begin{array}{c}\text { B. cereus } \\
\text { ATCC } 33018\end{array}$} & \multicolumn{2}{|c|}{$\begin{array}{l}\text { E. coli } \\
\text { Ec } 27\end{array}$} \\
\hline & MIC & $\begin{array}{c}\text { EOCv } \\
(8 \mu \mathrm{g} / \mathrm{ml})\end{array}$ & MIC & $\begin{array}{c}\text { EOCv } \\
(8 \mu \mathrm{g} / \mathrm{ml})\end{array}$ & MIC & $\begin{array}{c}\text { EOCv } \\
(8 \mu \mathrm{g} / \mathrm{ml})\end{array}$ \\
\hline Neomycin & $128 \pm 0.01$ & $64 \pm 0.01$ & $128 \pm 0.01$ & $64 \pm 0.54$ & $256 \pm 0.01$ & $128 \pm 0.11$ \\
\hline Amikacin & $256 \pm 0.01$ & $64 \pm 0.00$ & $256 \pm 0.01$ & $64 \pm 0.63$ & $256 \pm 0.01$ & $64 \pm 0.76$ \\
\hline Kanamycin & $64 \pm 0.12$ & $64 \pm 0.02$ & $64 \pm 0.02$ & $64 \pm 0.11$ & $64 \pm 0.02$ & $32 \pm 0.12$ \\
\hline Gentamicin & $128 \pm 0.03$ & $256 \pm 0.00$ & $128 \pm 0.01$ & $256 \pm 0.12$ & $256 \pm 0.01$ & $256 \pm 0.11$ \\
\hline
\end{tabular}

EOCv: Essential oil from Cordia verbenacea, MIC: Minimal inhibitory concentration 
phytoconstituents) can modify the antibiotic activity by the modulation or reversion of bacterial resistance. Besides this, natural products can interfere with the expected result of antibiotics through alteration of the susceptibility of microbes to these drugs. ${ }^{[2]}$ Although the antibiotics of microbial origin have been used in medical practice since 1940s, the use of antimicrobials of plant source is still incipient. Therefore, there are many reasons that stimulate the studies about new molecules, from phytochemicals, with antimicrobial properties. Between these properties, it is important to emphasize the growth of microorganisms resistance to traditional antimicrobials and the major sensitivity of patients treated with immunosuppressive drugs to get infected. ${ }^{[27]}$

The ability of essential oils to inhibit the bacterial growth of Gram-negative strains demonstrate a relevant result, once that is commonly described at literature that essential oils are active against Gram-positive because they are more sensitive to antibiotics. Gram-negative bacteria present structural particularities that make the penetration of aminoglycosides difficult, as the external layer of lipopolysaccharides that determines the surface properties, such as permeability and susceptibility to antibiotics. ${ }^{[28]}$

In conclusion, the results obtained in this investigation suggest that the volatile compounds of $C$. verbenacea essential oil may suppress the growth of bacterial pathogens and could be a source of secondary metabolites with antibacterial-modifying activity to be used as adjuvant in antibiotic therapy against pathogens. While there is scientific evidence on anti-inflammatory activity of essential oil, match any account of this antimicrobial activity reported. Therefore, further research should be encouraged to identify more natural compounds with synergistic behavior.

\section{REFERENCES}

1. Sertié JA, Basile AC, Panizza S, Matida AK, Zelnik R. Antiinflammatory activity and sub-acute toxicity ofartemetin. Planta Med 1990;56:36-40.

2. Balandrin MF, Klocke JA, Wurtele ES, Bllinger WH. Natural plant chemicals: Sources of industrial and medicinal materials. Science 1985;228:1154-60.

3. Carson CF, Cookson BD, Farrelly HD, Riley TV. Susceptibility of methicillin-resistant Staphylococcus aureus to the essential oil of Melaleuca alternifolia. J Antimicrob Chemother 1995;35:421-4.

4. Bhavanani SM, Ballow $\mathrm{CH}$. New agents for Gram-positive bacteria. Curr Opin Microbiol 2000;3:528-34.

5. Hendra R, Ahmad S, Sukari A, Shukor MY, Oskoueian E. Flavonoid analyses and antimicrobial activity of various parts of Phaleria macrocarpa (Scheff.) boerl fruit. Int $\mathrm{J}$ Mol Sci 2011;12:3422-31.

6. Akisue MK, Oliveira F, Moraes MS, Akisue G, Mancini B. Caracterização farmacognóstica da droga e da tintura de Cordia verbenacea A. DC. - BORAGINACEAE. Rev Bras Cienc Farm 1983;5:69-82.

7. Correa MP. Dicionário de plantas úteis do Brasil e das exóticas cultivadas. V.6; Rio de Janeiro/Brasília: Imprensa Nacional Brasília, Ministério da Agricultura; 1984. p. 312-3.

8. Lorenzi H, Matos FJ. Plantas medicinais do Brasil: Nativas e exóticas. Nova Odessa: Instituto Plantarum de Estados de Flora; 2002. p. 512.

9. Souza GC, Haas AP, Von Poser GL, Schapoval EE, Elisabetsky E. Ethnopharmacological studies of antimicrobial remedies in the south of Brazil. J Ethnopharmacol 2004;90:135-43.

10. Carvalho Junior PM, Rodrigues RF, Sawaya AC, Marques MO, Shimizu MT. Chemical composition and antimicrobial activity of the essential oil of Cordia verbenacea DC. J Ethnopharmacol 2004;95:297-301.

11. Velde VV, Lavie D, Zelnik R, Matida AK. Cordialin A and B, two new triterpenes from Cordia verbenacea DC. J Chem Soc Perkin Trans 1982;1:2697-700.

12. Adams R. Identification of essential oil components by gas chromatography/mass spectorscopy. $4^{\text {th }}$ ed. Carol Stream, Illinois: Allured Publishing Corporation; c2007. viii. 804. p. 28.

13. National Committee for Clinical Laboratory Standards - NCCLS. Reference method for broth dilution antifungal susceptibility testing of yeasts. Villanova, NCCLS. (Document M7-A6); 2002. p. 17.

14. National Committee for Clinical Laboratory Standards - NCCLS. Reference method for broth dilution antifungal susceptibility testing of yeasts. Villanova, NCCLS. (Document M38-A); 2002. p. 17.

15. Salvat A, Antonacci L, Fortunato RH, Suarez EY, Godoy HM. Screening of some plants from northern Argentina for their antimicrobial activity. Lett Appl Microbiol 2001;32:293-7.

16. Sagdiç O. Sensitivity of four pathogenic bacteria to Turkish thyme and Oregano hydrossols. Lebenson Wiss Technol 2003;36:467-73.

17. Henriques AT, Simões-Pires CA, Apel MA. Óleos essenciais, importância e perspectivas terapêuticas, In: Yunes RA, e Cechinel Filho V, editors. Química de produtos naturais, novos fármacos e a moderna farmagnosia. Itajaí: Ed Univale; 2007. p. 303.

18. Jorge LI, Markaman BE, Gonzalez E, Ferro VO. Identificação de Cordia verbenaceae D.C. (erva baleeira) como fitoterápico. Rev Bras Farm 1998;79:69-71.

19. Kitzberger CS, Smânia Júnior A, Pedrosa RC, Ferreira SR. Antioxidant and antimicrobial activities of shiitake (Lentinula edodes) extracts obtained by organic solvents and supercritical fluids. J Food Eng 2007;80:631-8.

20. Pinto MS, Faria JE, Message D, Cassini ST, Pereira CS, Gioso MM. Efeito de extratos de própolis verde sobre bactérias patogênicas isoladas do leite de vacas com mastite. Braz J Vet Res Anim Sci 2001;38:278-83.

21. Phelps CE. Bug/drug resistance: Sometimes less is more. Med Care 1989;27:194-203.

22. Oliveira FP, Lima EO, Siqueira Júnior JP, Souza EL, Santos $\mathrm{BH}$, Barreto HM. Effectiveness of Lippia sidoides Cham. (Verbenaceae) essential oil in inhibiting the growth of Staphylococcus aureus strains isolated from clinical material. Rev Bras Farmacogn 2006;16:510-6.

23. Coutinho HD, Costa JG, Siqueira-Júnior JP, Lima EO. In vitro anti-staphylococcal activity of Hyptis martiusii Benth against methicillin-resistant Staphylococcus aureus-MRSA strains. Rev Bras Farmacogn 2008;18 Suppl:S670-5.

24. Portillo A, Vila R, Freixa B, Adzet T, Cañigueral S. Antifungal activity of Paraguayan plants used in traditional medicine. J Ethnopharnacol 2001;76:93-8. 
25. Duarte MC. Atividade antimicrobiana de plantas medicinais e aromáticas utilizadas no Brasil. Rev Multiciências 2006;7:1-16. [periódicos na Internet]. Available from: http://www.multiciencia. unicamp.br/artigos_0 7/a_05_7.pdf >. [Last accessed on 2010 Jul 15].

26. Gibbons S. Anti-staphylococcal plant natural products. Nat Prod Rep 2004;21:263-77.

27. Cowan MM. Plant products as antimicrobial agents. Clin Microbiol Rev 1999;12:564-82.

28. Yokota S, Fullii N. Contributions of the lipopolysaccharide outer core oligosaccharide region on the cell surface properties of Pseudomonas aeruginosa. Comp Immunol Microbiol Infect Dis 2007;30:97-109.

Cite this article as: Rodrigues FF, Oliveira LG, Rodrigues FF, Saraiva ME, Almeida SC, Cabral ME, et al. Chemical composition, antibacterial and antifungal activities of essential oil from Cordia verbenacea DC leaves. Phcog Res 2012;4:161-5.

Source of Support: Nil, Conflict of Interest: None declared.

\section{Author Help: Online Submission of the Manuscripts}

Articles can be submitted online from http://www.journalonweb.com. For online submission articles should be prepared in two files (first page file and article file). Images should be submitted separately.

\section{1) First Page File:}

Prepare the title page, covering letter, acknowledgement, etc., using a word processor program. All information which can reveal your identity should be here. Use text/rtf/doc/pdf files. Do not zip the files.

2) Article file:

The main text of the article, beginning from Abstract till References (including tables) should be in this file. Do not include any information (such as acknowledgement, your names in page headers, etc.) in this file. Use text/rtt/doc/pdf files. Do not zip the files. Limit the file size to $1 \mathrm{MB}$. Do not incorporate images in the file. If file size is large, graphs can be submitted as images separately without incorporating them in the article file to reduce the size of the file.

3) Images:

Submit good quality color images. Each image should be less than $\mathbf{4 0 9 6} \mathbf{~ k b ~ ( 4 ~ M B ) ~ i n ~ s i z e . ~ S i z e ~ o f ~ t h e ~ i m a g e ~ c a n ~ b e ~ r e d u c e d ~ b y ~ d e c r e a s i n g ~}$ the actual height and width of the images (keep up to about 6 inches and up to about 1200 pixels) or by reducing the quality of image. JPEG is the most suitable file format. The image quality should be good enough to judge the scientific value of the image. Always retain a good quality, high resolution image for print purpose. This high resolution image should be sent to the editorial office at the time of sending a revised article.

4) Legends:

Legends for the figures/images should be included at the end of the article file. 